Status Report 2016-2019

\title{
Geology of the Proterozoic Eastern Ghats Belt: Recent Developments and Outstanding Issues
}

\author{
SANKAR BOSE* \\ Centre of Advanced Study, Department of Geology, Presidency University, Kolkata 700 073, India
}

(Received on 27 August 2019; Accepted on 15 October 2019)

\begin{abstract}
The Eastern Ghats Belt of India has remained a focus for intensive research over three decades. Its unusual rock assemblages, anomalous thermal conditions of metamorphism and consanguinity with the East Antarctica for a considerable geological time has made it a unique case study. This apparently monotonous terrane bears the fingerprint of a complex and fascinating journey of the Indo-Antarctic continental block during Earth's middle age. The paper collates the recent findings from this terrane and presents a status report with yet-to-be resolved issues in the light of current literature.
\end{abstract}

\section{Introduction}

The deeply eroded façade of Proterozoic Eastern Ghats Belt (EGB) attracted the geoscientists of diverse background over last thirty years. It all started with the publication of a major petrological study in the late eighties (Lal et al., 1987) which followed a vast number of data over the years (reviewed in Dasgupta et al., 2017). A majority of this dataset belongs to the petrological issues, yet limited contribution from geochemical, geophysical, structural and isotopic components have also poured in. From these data, several key statements can be made about the geological evolution of EGB. These are (1) a considerable part of EGB experienced the effect of ultrahigh temperature (UHT) metamorphism albeit in two different time spans, (2) the tectonic setting that caused UHT metamorphism, charnockite magmatism, regional extension followed by compression and related features was dominated by subduction-accretion in two important segments of the Proterozoic era, (3) the counter-clockwise pressure-temperature path leading to UHT peak is a hallmark of EGB which matches with the aforementioned tectonic setting, (4) the geological similarities between EGB and parts of East Antarctica that lead to reconstruction of the supercontinents Gondwana, Rodinia and possibly, Columbia, and (5) the evolution of EGB is inseparable with the evolution of Greater Indian Landmass (GIL). These key issues may be taken as time-tested facts and their implications provided significant knowledge regarding the evolution of Earth during its middle age (ca. 2000-500 Ma). Apart from these, several other important issues have cropped up from the EGB which also provided important clues regarding the chemical and physical changes of lower crust during orogenesis.

The present compilation is a status report on the evolution of EGB and I will be focusing mostly on the data published in last two years (since 2016). An earlier review by Dasgupta et al. (2017) described all the major issues outstanding until early 2016 and will not be repeated as far as practicable. However, one important aspect regarding the geological diversity of EGB needs to be mentioned here. Although no detailed geological map is available for this $1000 \mathrm{~km}$ long terrane, earlier efforts by the scientists of the Geological Survey of India made it possible to make a broad geological map (Fig. la after Ramakrishnan et al., 1998). Based on the broad lithological dispositions (mostly charnockites and khondalites), these authors made longitudinal subdivisions of EGB into four zones with a tacit assumption that these zones represent different time histories of the EGB. Incidentally, the first precision geochronological data from EGB came into light at

*Author for Correspondence: E-mail: sankar.geol@presiuniv.ac.in 


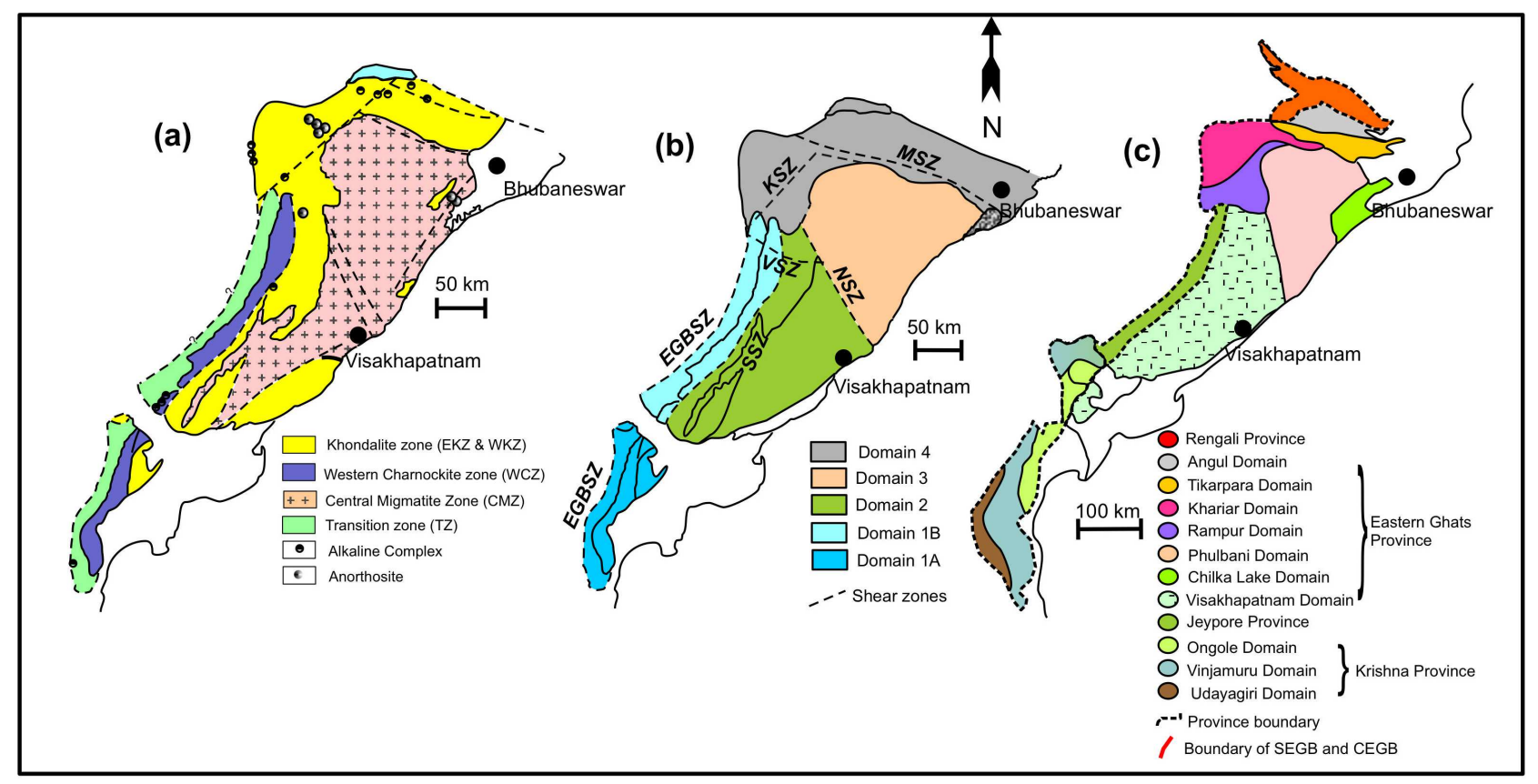

Fig. 1: Geological map of the EGB (a) after Ramakrishnan et al., 1998, (b) after Rickers et al., (2001), (c) after Dobmeier and Raith (2003)

the same time (Shaw et al., 1997; Mezger and Cosca, 1999) and it became apparent from these data that there is a considerable time difference of high-grade (including UHT) metamorphism and magmatism between the segment of EGB occurring north and south of the Godavari rift. The idea that EGB is a collage of crustal block got a major fillip with the publication of the first isotopic map of the terrane (Fig. 1b after Rickers et al., 2001). This eventually led to the domain and province-based classification of EGB (Fig. 1c after Dobmeier and Raith, 2003). Therefore, any study made thereafter, considered EGB as a collage of four geological provinces (Krishna, Jeypore, Eastern Ghats and Rengali) within which several crustal domains are joined together. In the present compilation, I am also following the same subdivisions to present the current status. However, the recent data also allowed me to reconsider the rationale behind domain-based classification which I will explain in the later part.

\section{The Krishna Province}

The Krishna Province after Dobmeier and Raith (2003) is analogous to the isotopic Domain 1A of Rickers et al. (2001). Accordingly, this province is constituted of three crustal domains, namely the
Vinjamuru, the Udaygiri and the Ongole domains (Fig. 1c). Out of these, the first two domains are represented by magmatic (both felsic and mafic) and metamorphic rocks of low to medium grade, whereas the Ongole domain is characterized by broadly granulite facies rocks including the UHT occurrences. The Vinjamuru and Udaygiri domains have known occurrences of extensive schist belts that were known by Nellore and Khammam schist belts in earlier literature. The metasediment-dominated Udaygiri domain is interpreted to have thrusted over the metabasalt-dominated Vinjamuru domain along a westerly dipping thrust (Das et al., 2016). This thrusting occurred along dextral strike slip motion during E-W compression. The Vinjamuru metabasalts were formed in an island arc setting coupled with a probable back-arc activity (Das and Shukla, 2017). The tectonic setting of this terrane is controversial as contrasting model for long-lived subduction (Dharma Rao and Santosh, 2011) and collision of India and Napier Complex of East Antarctica (Vijaya Kumar et al., 2011, 2019; Ranjan et al., 2018) exist. In a recent work, Chatterjee et al. (2016) proposed a third model based on geochemical study where they proposed a Cordilleran-type accretion involving the East Dharwar Craton (EDC) and North China Craton 
(NCC) at ca. $1.78 \mathrm{Ga}$. These models have both merits and demerits, but the role of presently separated cratonic blocks needs to be verified from more direct evidences like paleomagnetic data. Two important ophiolitic complexes occur in these domains which are of recurrent geologic interest in recent time. The Kandra Ophiolitic Complex (KOC) of ca. 1.9 Ga age represents the suprasubduction zone backarc setting, which was tectonically juxtaposed against the EDC (Saha et al., 2017). These workers demonstrated the stratigraphic succession of the KOC in terms of variation of sedimentary characters of the ocean plate stratigraphy.

The ca. 1.33 Ga Kanigiri Ophiolite (KO), on the other hand, represents the intraoceanic subduction outboard of the EDC which was accreted simultaneously with the Ongole domain and the Nellore schist belt on the margin of the EDC during the breakup of Rodinia (Sain and Saha, 2018). This subduction-accretion process of KO was succeeded by the emplacement of post-orogenic granite at ca. $1.284 \mathrm{Ga}$ (Sain et al., 2017). This process operated simultaneously with development of the Prakasham Igneous Province where mafic magmatism occurred at ca. $1.315 \mathrm{Ga}$ in a broad subduction setting (Subramanyam et al., 2016). Interestingly, trace of a sedimentary basin has recently been identified inbetween the Archean basement (EDC) and the Nellore schist belt, based on deep sounding seismic data (Chandrakala et al., 2017). The authors consider that the sediment was deposited in this basin from the eroding orogenic belts formed during the assembly of Columbia and Rodinia. This interpretation is problematic based on the stratigraphic point of view and a more direct evidence is needed to identify the sediment provenance of this buried basin.

The granulite-dominated Ongole domain has an identified UHT metamorphic history (described in detail by Dasgupta et al., 2017). In a recent work, Sarkar and Schenk (2016) demonstrated the geological evolution of this domain involving two separate and contrasting metamorphic cycles. The initial medium - pressure counter-clockwise P-T path culminating in UHT condition resulted from magmatic accretion of the Kondapalle magmatic arc at ca. 1.75$1.60 \mathrm{Ga}$. Recent zircon U-Pb data (ca. $1.715 \mathrm{Ga}$ ) from mafic granulite also validate this time frame (Vijaya Kumar et al., 2019). This was succeeded by the high-pressure medium temperature clockwise P$\mathrm{T}$ path, which was caused by tectonic crustal thickening at ca. $1.54 \mathrm{Ga}$. Accordingly, these authors interpreted a protracted evolutionary history of the supercontinent Columbia, a notion which has been disputed in recent time (Bhowmik, 2019).

Emplacement of alkaline rocks at ca. $1.35 \mathrm{Ga}$ (Ranjan et al., 2018) marked a major shift from compressional to extensional tectonic setting with the opening of an ocean basin between India (cratonic India + Ongole domain + Napier Complex) and cratonic East Antarctica (Ruker Province) during disintegration of Columbia. The Ongole domain did not suffer from any high-grade event thereafter.

\section{The Eastern Ghats Province}

A major part of EGB occurring north of the Godavari rift and a small triangular segment south of it is brought into this province. The Eastern and Western Khondalite Zone, as well as the Central Migmatite Zone of Ramakrishnan et al. (1998) belong to this, while the isotopic Domain 2, 3 and part of Domain 4 of Rickers et al. (2001) can be accommodated in this province (Fig. 2). Most of the UHT occurrences were reported from this province where the characteristic $\mathrm{P}-\mathrm{T}$ path is counter-clockwise and the major tectonothermal events occurred at ca. 1.0-0.9 Ga (reviewed in Dasgupta et al., 2017). Notwithstanding this mostly accepted metamorphic history, there are major disagreements on several issues. It was postulated in earlier studies that sediments were deposited with the opening of ocean basin at ca. 1.4$1.2 \mathrm{Ga}$ (Upadhyay et al., 2008). Recent studies indicate a major phase of granitic basement formation at ca. $1.17 \mathrm{Ga}$ (Ganguly et al., 2018). On the other hand, Kelsey et al. (2017) reported mafic magmatic emplacement at ca. $1.58 \mathrm{Ga}$ which implies crustal formation was complete in some parts of the province, a notion which is not reflected in any detrital zircon study carried out earlier (Upadhyay et al., 2009). Mafic granulite from the Vishakhapatnam-Koraput area recorded fluctuation of fluid regime (in terms of $f \mathrm{O} 2$ ) during metamorphism which is reflected in complex oxide-silicate-sulphide-sulphate mineralogy (Mondal and Bose, 2019). There is still an ongoing debate on the timing of UHT metamorphism. Although it is more or less agreed upon that the time frame is ca. 1050-990 Ma (Dasgupta et al., 2017; 


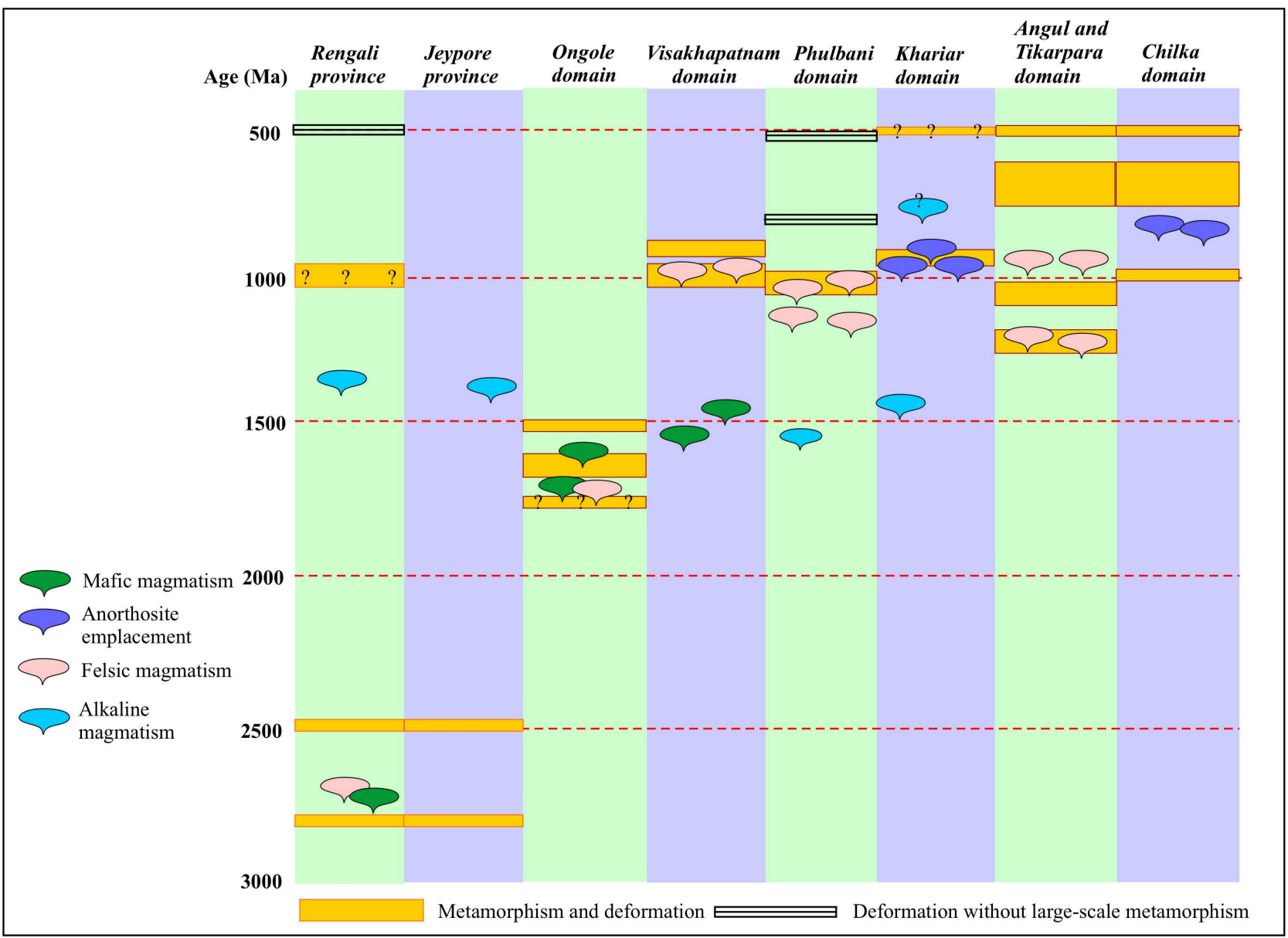

Fig. 2: Metamorphic, magmatic and deformation histories of different domains and provinces of EGB and its adjoining cratons (after Ganguly, 2019)

Mitchell et al., 2018), Das et al. (2017) reported ca. $1.17 \mathrm{Ga}$ UHT event based on monazite data. Strangely, this latter age coincides with the granitic emplacement age at Phulbani area (Ganguly et al., 2017, 2018). The latter area (cited as Phulbani domain), remained largely uncharacterized until recent times, gained international focus due to its reported occurrence of ca. $0.99 \mathrm{Ga}$ UHT rocks which were intruded by porphyritic charnockite at ca. 0.97 Ga (Ganguly et al., 2018). The P-T-t history of this domain is quite similar to the adjacent Visakhapatnam domain despite the presence of the NagavalliVamshadhara shear zones in-between. No new petrological data came from the Angul, Tikarpara and Rampur domains. Based on the structural data, Bose and Gupta (2018) proposed dextral strike slip movement along the Mahanadi shear zone, which presumably occurred at ca. $0.5 \mathrm{Ga}$ as determined by earlier studies (Lisker and Fachman, 2001; Crowe et al., 2001). The Chilka domain has a complex history dominated by ca. 0.99 Ga UHT metamorphism, followed by cooling, ca. $0.78 \mathrm{Ga}$ decompression and reworking at ca. $0.53 \mathrm{Ga}$ (Bose et al., 2016a). New geochronological data have been presented from the Koraput Alkaline Complex, which lies at the junction of the Khariar domain and the Jeypore Province. While Nanda et al. (2018) argued that the alkaline complex intruded the EGP at ca. $850 \mathrm{Ma}$, Ranjan et al. (2018) reported the intrusion age of the same complex as ca. $1387 \mathrm{Ma}$. The younger age could be related to the fragmentation of Rodinia, but the older age matches with the fragmentation of Columbia. It is intriguing how fragmentation history of two supercontinents can be preserved in the same rock suite. Nanda et al. (2018) also reported the age of granulite metamorphism of the alkaline complex as $0.7 \mathrm{Ga}$ which was preceded by a thrusting event of the EGP over the Jeypore Province. On the other 
hand, new geochronological data from the southwestern part of the Khariar domain suggest two separate thrusting (cum metamorphism) event where the rocks of the EGP were initially thrusted on the Bastar Craton at ca. 0.9 Ga followed by another thrusting at ca. $0.5 \mathrm{Ga}$ (Chatterjee et al., 2017a, b). These authors further proposed that the thrusting continued until the Cambrian time.

There is a recent discrepancy regarding the nature of P-T loop for the Eastern Ghats Province. The existing counter-clockwise P-T path (Dasgupta et al., 2017) which has been validated in the study of Kelsey et al. (2017) from the Visakhapatnam domain has been contradicted by Mitchell et al. (2018) from the same domain. The latter study also refuted the model of short-lived two-cycle orogeny for this province (ca. 1.03-0.99 Ga and 0.95-0.90 Ga by Bose et al., 2011; Das et al., 2011, cited in Dasgupta et al., 2017) and proposed a monocycle long-lived orogeny. In the case of two-cycle orogenesis, a major phase of isothermal decompression occurred as recorded in the study of Kelsey et al. (2017). Mitchell et al. (2018) ruled out this decompression event but reserved comments on how the hot lower crustal granulites resided in the middle crust up to ca. 0.55 Ga before exhumation. The latter age represents amphibolite facies (Dasgupta et al., 2017; Kelsey et al., 2017) to locally granulite facies (Mitchell et al., 2018) reworking of the cooled granulites during the Pan African orogeny.

The Chilka domain has a unique lithological association, but its boundaries are not well- defined. A review of the literature on metamorphic evolution of the rocks of this domain shows convergence in opinion about one phase of UHT metamorphism at ca.1.0 Ga (Bose et al., 2016a). Tectonothermal reworking of UHT granulites has been constrained within the time frame $0.8-0.5 \mathrm{Ga}$ (Bose et al., 2016a). These later events are similar to those deduced by Mitchell et al. (2018) from the Visakhapatnam domain. While the event at $0.8 \mathrm{Ga}$ coincides with the known time of disintegration of the supercontinent Rodinia, documentation of high grade (granulite facies) re-metamorphism at ca. $0.5 \mathrm{Ga}$ in both the domains (Mitchell et al., 2018; Bose et al., 2016a respectively) has important implications in the assembly of East Gondwana and correlation of parts of the EGB with east Antarctica.

\section{The Jeypore Province}

The Jeypore Province is equivalent to the isotopic Domain 1B of Rickers et al. (2001) and dominantly composed of mafic granulite and charnockite which are bounded by major shear zones against the Bastar Craton. Despite the importance of crustal amalgamation, rocks of this province are least studied regarding the nature and timing of metamorphism as well as the structural and tectonic history. Apart from recent data of Nanda et al. (2018) in the alkaline complex, the timing of thrusting between the craton and mobile belt is also unclear. Monazite chemical age data from Koraput anorthosite yield three groups, at ca. $0.94 \mathrm{Ga}$, ca. $0.88-0.75 \mathrm{Ga}$ and ca. $0.57 \mathrm{Ga}$ (Saikia et al., 2018). The authors suggest that the oldest age reflects emplacement of the anorthosite magma, while the intermediate age reflects the breakup of Rodinia and the youngest one is the timing of assembly of Gondwana. No metamorphic imprint older than ca. $1.5 \mathrm{Ga}$ is reported from this province, and clearly a lot of work needs to be done in future.

\section{The Rengali Province}

This province of Dobmeier and Raith (2003) is equivalent to the isotopic Domain 4 of Rickers et al. (2001) and is separated from the Eastern Ghats Province by a strip of Gondwana sediments (Fig. 1c). The rocks of this province have greenschist to granulite facies metamorphic signatures, which is starkly different from the northerly occurring Singhbhum Craton and the southerly occurring Eastern Ghats Province. The gneissic basement of this province is composed of granitoids (A. Dasgupta et al., 2017) showing amphibolite to granulite facies metamorphism that occurred during ca. 3.0-2.5 Ga (Bose et al., 2016b and references therein). The supracrustal sequences that lie over the basement show greenschist facies metamorphism and represent multiple cycles of basin development during the Neoarchean-Mesoproterozoic time frame (K. Das et al., 2017). Alkaline rocks from this province were emplaced at ca. $1.35 \mathrm{Ga}$ (Ranjan et al., 2018). Geological data suggest that this province is a deeper section of the Singhbhum Craton which was structurally emplaced in the shallow level by a transpression-dominated tectonic setting at ca. $0.5 \mathrm{Ga}$ (Ghosh et al., 2016 and others cited in Bose and Dasgupta, 2018). Barring a single occurrence of ca. 
1.0 Ga metamorphism (Chattopadhyay et al., 2015), no clear indication of Grenville-age metamorphism which is characteristic of the Eastern Ghats Province, is recorded from here. In an alternative model, the Rengali Province represents a part of the Bastar Craton which was transported over the Eastern Ghats Province by a dextral strike slip movement at ca. 0.5 Ga (Sawant et al., 2017 and references therein). The latter workers correlated the Eastern Ghats-Rengali contact zone and the Rauer Group of East Antarctica that also evolved as a ca. $0.5 \mathrm{Ga}$ strike-slip shear zone. Thus, more geological data are required to delineate the ancestry of Rengali Province.

\section{Outstanding Issues of the EGB}

\section{Domains and Provinces}

In the published literature, present configuration of EGB is conceived as an amalgam of discrete provinces and domains. These provinces and domains are believed to have juxtaposed by boundary ductile shear zones assuming these are true terrane boundaries. With growing evidences, it is now time to rethink about this classification. Considering the lithological continuity across the shear zones and the timing(s) of the activation of some of the shear zones, it is clear that majority of the crustal domains of the Eastern Ghats Province evolved as a single entity (Fig. 2 after Ganguly, 2019). Although geological histories of the Eastern Ghats Province and the Ongole domain are significantly different in time frame, there is no unambiguous evidence to consider the fact that the individual domains in the former evolved differently. The status of the Jeypore Province or domain 1B is unclear as no recent data are available. This could be a separate terrane comprising the exhumed deeper margin of the Bastar Craton analogous to the Rengali Province, which is the exhumed deeper margin of the Singhbhum Craton. Careful orchestration of petrological and isotope investigations is required to resolve these issues.

\section{EGB and Rodinia}

It is generally agreed upon that different segment (domains and/or provinces) of the EGB evolved during the accretionary growth of Proterozoic supercontinents (Dasgupta et al., 2013, 2017; Bose and Dasgupta, 2018). The metamorphic age provinces of EGB show a strong dominance of the ca. 1000-900 Ma and ca. 1800-1600 Ma events with sporadic presence of ca. 500 Ma events along the shear zones (Fig. 3). The Ongole domain evolved along with the Napier Complex of East Antarctica during the growth of Columbia (references as above). On the other hand, the evolution of the Eastern Ghats Province could be linked with the evolution of Rodinia. Recent studies from the Rayner Complex also support this (Tong et al., 2017). Although the position of India within Rodinia is a matter of conjecture (reviewed in Dasgupta et al., 2017; Bose and Dasgupta, 2018; Mitchell et al., 2018), it is accepted that the Eastern Ghats Province formed a composite orogen with the Rayner Province (R-EG orogen of Morissey et al., $2015,2016)$ at ca. 1.0-0.9 Ga possibly as a part of Rodinia. Paleomagnetic tools can directly resolve the issue, but the deformed and intensely metamorphosed rocks of EGB are not ideally suited for this purpose. Whether part of Rodinia or not, it is however, agreed upon that the evolution of R- EG resulted from subduction-dominated accretionary tectonics involving cratonic India and East Antarctica (Van Leeuwen et al., 2019). It is now important to identify which part of the Eastern Ghats Province can be matched with which part of the Rayner Province. It is already proposed that the Chilka lake domain was a part of the Prydz Bay area of the Rayner Province (Bose et al., 2016a). With more petrological and geochronological inputs from both sides of the great divide, one can precisely fit the Grenville-age crustal fragments in the India-Antarctica frame. Based on the geochronological evidence, records of assembly of the East Gondwana supercontinent has also been proposed from the EGB in recent time (Mitchell et al., 2018). It is intriguing to note how a single orogenic belt underwent two (or three) supercontinent cycles during the Proterozoic era.

\section{Style and Duration of Orogenic Cycle in the Eastern Ghats Province}

Although the occurrence of UHT metamorphism is well-documented, debate is still going on to explain the anomalous thermal perturbation that was experienced by the Eastern Ghats Province at ca. 1.0 Ga. Models predicting back arc tectonic setting to truncated hot orogen with contributions from high concentrations of heat producing elements and slab break- off/lithospheric delamination have been invoked to explain UHT metamorphism in this belt 


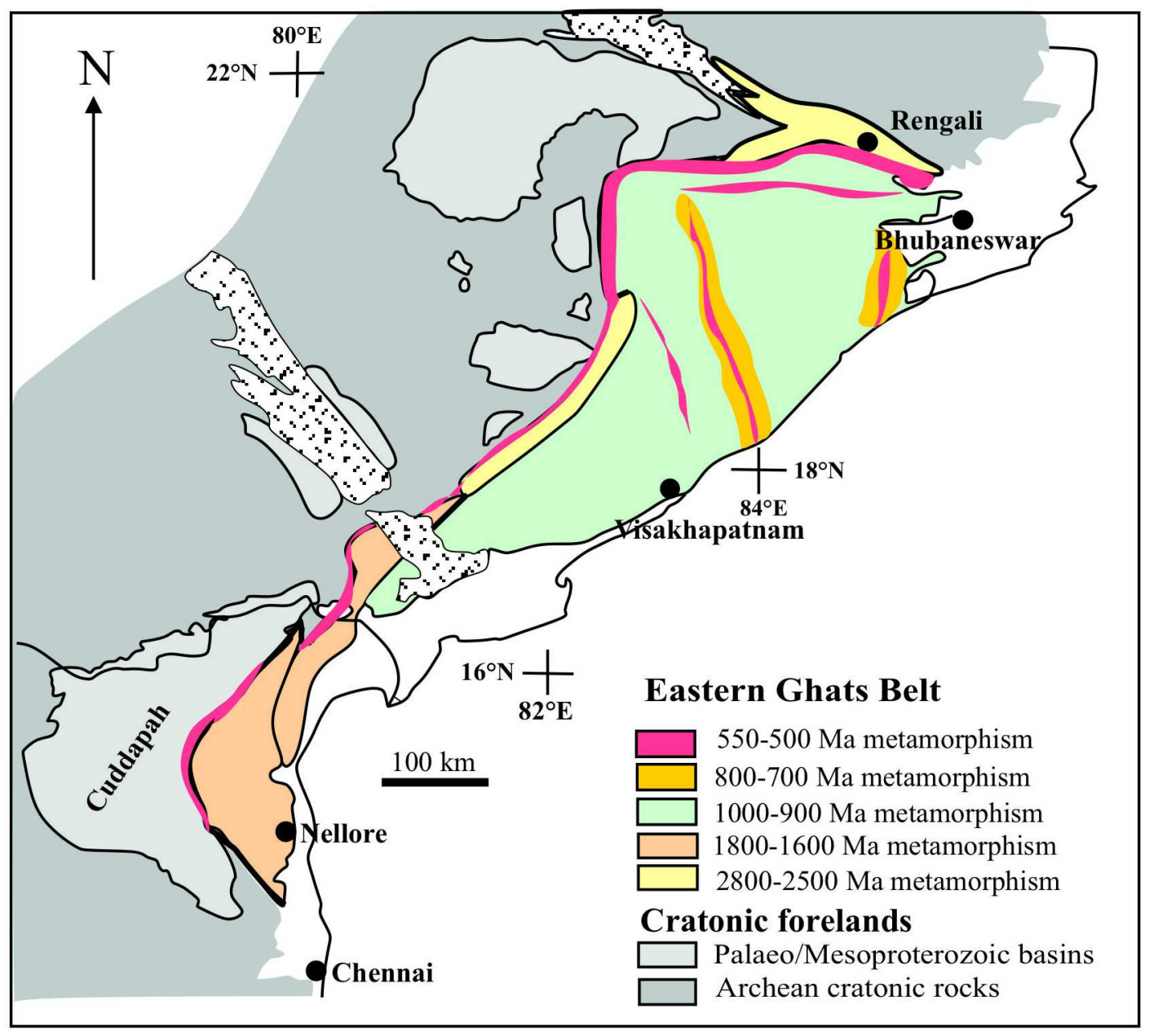

Fig. 3: Metamorphic age provinces of EGB compiled from data presented in the text

(see reviews in Dasgupta et al., 2017; Mitchell et al., 2018; Bose and Dasgupta, 2018). This seems to be the only viable model so far, but opinions are still divergent on the time scale of this accretionary growth history. While some workers are of the opinion that the entire process went to completion at one go with existence of a long-lived hot orogen (Korhonen et al., 2013a), others argue for short-lived repeated orogenesis (Dasgupta et al., 2013, 2017; Bose and Dasgupta, 2018). One important approach to resolve this issue could be kinetic modelling as a recent study showed that multiple episodes of "short-lived" orogenies could be traced back from the complexly evolved Proterozoic orogenic system (Bhowmik and Chakraborty, 2017). This is an important distinction to be made to explain the tectonic setting in the Proterozoic era. It is a fact that, the EGB as an entirety experienced at least one phase of UHT metamorphism at mid- lower crustal depths, but at different times in various segments. Therefore, apart from the cause of UHT metamorphism, it is important to evaluate whether tectonic settings were similar or different, and why these were recurrent in time. The timing of supercontinent assembly cannot be just coincidental without a secular change in plate tectonic style (Brown and Johnson, 2018).

\section{Exhumation of Deep Crust and the Shear Zones}

One key issue which remains untouched for decades is how the isobarically cooled deep crust of the EGB got exhumed at shallower level. Excepting a few cases, the UHT granulites do not exhibit a decompression-dominated P-T path, which implies large-scale exhumation at high temperature did not occur. It is prudent to conceive the crisscrossing ductile shear zones as the principal conduits for exhumation of deeper crust (tectonic exhumation) at 
later time. Very little work has been done on this issue and the kinematics of the major shear zones remain poorly characterized so far. The assumption that the ductile shear zones are terrane boundaries is not valid for many cases. For example, the N-S trending Nagavalli-Vamshadhara Shear Zone (NVSZ) was originally considered as a terrane boundary suturing the Vishakhapatnam and Phulbani domains. In a recent study, it is shown that the rocks exposed on both sides of the NVSZ show similar metamorphic and geochronological histories. The activation of such shear zones must be younger in age, but could not be dated using precision geochronological tools. While data (K-Ar, Ar-Ar) from the Mahanadi and Ranipathar shear zone indicate a Pan-African age, the age of others remain still uncertain. It is also possible that a majority of these shear zones are intracrustal in nature and formed due to far field stress (Ravikant, 2019; Ganguly et al., 2019).

\section{Juxtaposition of EGB with Cratonic India}

Timing of juxtaposition of EGB with cratonic India is still a debated topic. While there are models suggesting thrusting of EGB over the Bastar Craton at ca. 1.0-0.9 Ga (Ranjan et al., 2018 and references therein), the alternate model suggests a Pan-African (ca. 0.55-0.50 Ga) thrusting (Nasipuri et al., 2018). It is, however, possible that there exist two thrusting events and the earlier thrusts are buried under the younger thrusts, which was conceived earlier (Upadhyay, 2008). In recent work, Chatterjee et al. (2017b) identified two different age domains (ca. 1.0$0.9 \mathrm{Ga}$ and ca. 0.55-0.50 Ga) from the EGB-Bastar contact. While it is understood that the identification of possible counterparts of the EGB in east Antarctica will be speculative, detail petrological, isotopic and structural investigations are required along the contacts of EGB with the three cratonic blocks to ascertain whether the cratonization of the EGB was completed by ca. $1.0 \mathrm{Ga}$ or at ca. $0.5 \mathrm{Ga}$ to define the present crustal architecture of India.

\section{The missing Grenvillian-age Suture}

The nature and location of the proposed Grenvillianage $(\sim 0.9 \mathrm{Ga})$ suture between India and East Antarctica is "missing" information in the reconstruction hypothesis. The western boundary of EGB has long been thought of as a suture although no unambiguous evidence of ocean closure like presence of ophiolite is identified. This has been elaborated recently in Bose and Dasgupta (2018) and they proposed that the true continental suture could be located in the interior part of the Prydz Bay region of East Antarctica. Therefore, the absence of such a suture at the western margin of EGB is not surprising.

Recent geophysical data across the EGB and adjoining Singhbhum and Bastar Cratons provide some interesting clues. The seismic profiles identified prominent Moho offsets which are interpreted as the evidence of collisional tectonics (Singh and Singh, 2019; Jana et al., 2019). However, the amount of Moho offset is small $(\sim 5 \mathrm{~km})$ which can be interpreted by accretionary tectonics (Dasgupta et al., 2013). This is also vindicated by the fact that no significant crustal thickening has been noted near the proposed suture (Singh and Singh, 2019). These geophysical signatures need to be correlated with the petrological, geochronological and structural data for unambiguous interpretations.

\section{Acknowledgements}

The author extends sincere thanks to Prof. Somnath Dasgupta for the invitation to write this review and Prof. D.M. Banerjee for the editorial handling. The author spent over two decades visiting places of EGB and shared ideas with Kaushik Das, Subrata Karmakar and Pulak Sengupta. Insightful discussions with Santanu Kumar Bhowmik have always been an enriching experience. The author also appreciates his doctoral students Proloy Ganguly and Arnab Dasgupta and Master's students of two decades for their sincere efforts to understand the complexity of EGB. His foreign collaborators Makoto Arima, Daniel Dunkley, Hiroshi Hidaka, Masato Fukuoka, Naotaka Tomioka and Junji Torimoto offered analytical and experimental support to a large extent. 


\section{References}

Bhowmik S K (2019) The current status of orogenesis in the Central Indian Tectonic Zone: a view from its southern margin Geol J doi: 10.1002/gj.3456.

Bhowmik S K and Chakraborty S (2017) Sequential kinetic modelling: A new tool decodes pulsed tectonic patterns in early hot orogens of Earth Earth Planet Sci Lett 460 171179

Bose S and Dasgupta S (2018) Eastern Ghats Belt, Grenvillianage tectonics and the evolution of the Greater Indian Landmass: a critical perspective J Ind Inst Sci 98 345-363

Bose S, Das K, Torimoto J, Arima M and Dunkley D J (2016a) Evolution of the Chilka Lake granulite complex, northern Eastern Ghats Belt, India: evidence of $\sim 780 \mathrm{Ma}$ decompression of the deep crust and its implication on the India-Antarctica correlation Lithos 263 161-189

Bose S, Das K, Kimura K, Hidaka H, Dasgupta A, Ghosh G and Mukhopadhyay J (2016b) Neoarchean tectonothermal imprints in the Rengali Province, eastern India and their implication on the growth of Singhbhum Craton: Evidence from zircon U-Pb SHRIMP data J Metamorph Geol 34 743-764

Bose S, Dunkley D J, Dasgupta S, Das K and Arima M (2011) India-Antarctica-Australia- Laurentia connection in the Paleo-Mesoproterozoic revisited: Evidence from new zircon $\mathrm{U}-\mathrm{Pb}$ and monazite chemical age data from the Eastern Ghats Belt, India Bull Geol Soc Am 123 20312049

Bose S and Gupta S (2018) Strain partitioning along the Mahanadi Shear Zone: implications for paleo-tectonics of the Eastern Ghats Province, India $J$ Asian Earth Sci 157 269-282

Brown M and Johnson T (2018) Secular change in metamorphism and the onset of global plate tectonics Am Mineral 103 181-196

Chandrakala K, Pandey O P, Sesha Sai V V, Vasanthi A, Satish Kumar K (2017) Seismically derived Gondwana and Proterozoic sediments east of Cuddapah basin, South Indian shield and its possible geotectonic implications Pure Appl Geophys doi: 10.1007/s00024-017-1560-8

Chatterjee A, Das K, Bose S and Hidaka H (2017a) Ageintegrated tectonic modelling across the orogen-craton boundary: Age zonation and shallow- to deep crustal participation during Late Cambrian cratonization of Eastern Ghats Belts, India Lithos 290-291 269-293

Chatterjee A, Das K, Bose S, Ganguly P and Hidaka H (2017b) Zircon U-Pb SHRIMP and monazite EPMA CHIME geochronology of granulites of the western boundary,
EGB, India: new evidence for Neoproterozoic exhumation history. In Crustal evolution of India and Antarctica: the supercontinent connection (Eds. Pant N C and Dasgupta S) pp 105-140 Geol Soc Lond Spec Pub 457

Chatterjee C, Ravikant V and Kaptan O P (2016) Paleoproterozoic Cordilleran-style accretion along the south eastern margin of the eastern Dharwar craton: evidence from the Vinjamuru arc terrane of the Krishna orogen, India Lithos 263 122-142

Chattopadhyay S, Upadhyay D, Nanda J K, Mezger K, Pruseth K L and Berndt J (2015) Proto- India was a part of Rodinia: evidence from Grenville-age suturing of the Eastern Ghats Province with the Paleoarchean Singhbhum Craton Precamb Res 266 506-529

Crowe W A, Cosca M A and Harris L B (2001) ${ }^{40} \mathrm{Ar} /{ }^{39} \mathrm{Ar}$ geochronology and Neoproterozoic tectonics along the northern margin of the Eastern Ghats Belt in north Orissa, India Precamb Res 108 237-266

Das S and Shukla D (2017) Geochemical signatures of island arc tholeiites from the Central- Western part of Nellore Schist belt, Pamuru-Udayagiri area, Andhra Pradesh, India Ind $J$ Geosc 70-71 247-262

Das S, Shukla D and Mitra S K (2016) Evidences of inclined transpression at the contact between Vinjamuru group and Udayagiri group of Nellore Schist Belt, Andhra Pradesh, India J Earth Sys Sci 125 1007-1020

Das E, Karmakar S, Dey A, Karmakar S and Sengupta P (2017) Reaction textures, pressure- temperature paths and chemical dates of monazite from a new suite of sapphirinespinel granulites from parts of the Eastern Ghats Province, India: insights into the final amalgamation of India and East Antarctica during the formation of Rodinia. In: Crustal evolution of India and Antarctica: the supercontinent connection (Eds. Pant N C and Dasgupta S) pp 141-170 Geol Soc Lond Spec Pub 457

Das K, Bose, S and Ghosh G (2017) The NeoarcheanPaleoproterozoic basin development and growth of the Singhbhum Craton, eastern India and its global implications: insights from detrital zircon $\mathrm{U}-\mathrm{Pb}$ data Precamb Res 298 123-145

Das K, Bose S, Karmakar S, Dunkley D J and Dasgupta S (2011) Multiple tectonometamorphic imprints in the lower crust: first evidence of c. 950 Ma compressional reworking of older UHT metamorphosed aluminous granulites from the Eastern Ghats Belt, India Geol J 46 217-239

Dasgupta A, Bose S, Ghosh G and Das K (2017) Petrological and geochemical evolution of the Central Gneissic Complex, Rengali Province, eastern India: implication for the 
Neoarchean orogenesis J Asian Earth Sci 146 1-19

Dasgupta S, Bose S, Bhowmik S K and Sengupta P (2017) Eastern Ghats Belt, India in the context of supercontinent assembly. In: Crustal evolution of India and Antarctica: the supercontinent connection (Eds. Pant N C and Dasgupta S) pp 87-104 Geol Soc Lond Spec Pub 457

Dasgupta S, Bose S and Das K (2013) Tectonic evolution of the Eastern Ghats Belt Precamb Res 227 247-258

Dharma Rao C V and Santosh M (2011) Continental arc magmatism in a Mesoproterozoic convergent margin: petrological and geochemical constraints from the magmatic suite of Kondapalle along the eastern margin of the Indian plate Tectonophysics 510 151-171

Dobmeier C and Raith M M (2003) Crustal architecture and evolution of the Eastern Ghats Belt and adjacent regions of India. In: Proterozoic East Gondwana: supercontinent assembly and breakup (Eds. Yoshida M, Windley B F and Dasgupta S) pp 169-202 Geol Soc Lond Spec Pub 206

Ganguly P (2019) Tectonothermal history of the granulites and gneisses around Phulbani, Odisha, India and its bearing on the evolution of the Proterozoic Eastern Ghats Belt. Ph.D. thesis Presidency University, Kolkata, 264 p

Ganguly P, Bose S, Das K, Torimoto J and Ghosh G (2017) Origin of spinel + quartz assemblage in a Si-undersaturated ultrahigh temperature aluminous granulite and its implication in the P-T-fluid history of the Phulbani domain, Eastern Ghats Belt, India J Petrol 58 1941-1974

Ganguly P, Das K, Bose S, Ghosh G, Hayasaka Y and Hidaka H (2018) U-Pb zircon and U-Th- total Pb monazite ages from the Phulbani Domain of the Eastern Ghats Belt, India: time constraints on high-grade metamorphism and magmatism in the lower crust Precamb Res 316 1-23

Ganguly P, Ghosh G, Das K and Bose S (2019) Structural fabric analysis of ultra-hot deep continental crust: Implications for tectonic evolution of northern Eastern Ghats Belt, India Tectonophysics (under review)

Ghosh G, Bose S, Das K, Dasgupta A, Yamamoto T, Hayasaka Y, Chakraborti K and Mukhopadhyay J (2016) Transpression and juxtaposition of middle crust over upper crust forming a crustal scale flower structure: Insight from structural, fabric, kinematic and geochronologic studies from the Rengali Province, eastern India J Struc Geol 83 156-179

Jana N, Singh A, Tiwari A K, Singh C and Biswas R (2019) Mantle deformation patterns and signatures of rift, beneath Eastern Ghats Mobile Belt Phys Earth Planet Int doi: 10.1016/j.pepi.2019.01.009.

Kelsey D E, Morrissey L J, Hand M, Clark C, Tamblyn R, Gaehl
A A and Marshall S (2017) Significance of post-peak metamorphic reaction microstructures in the ultrahigh temperature Eastern Ghats Province, India J Metamorph Geol 35 1081-1109

Lal R K, Ackermand D and Upadhyay H (1987) P-T-X relationships deduced from corona textures in sapphirinespinel-quartz assemblages from Paderu, southern India $J$ Petrol 28 1139-1168

Lisker F and Fachmann S (2001) The Phanerozoic history of the Mahanadi region, India $J$ Geophys Res Solid Earth 106 22027-22050

Mezger K and Cosca M A (1999) The thermal history of the Eastern Ghats Belt (India), as revealed by $\mathrm{U}-\mathrm{Pb}$ and ${ }^{40} \mathrm{Ar}-$

${ }^{39} \mathrm{Ar}$ dating of metamorphic and magmatic minerals: implications for the SWEAT correlation Precamb Res 94 251-271

Mitchell R J, Johnson T E, Clark C, Gupta S, Brown M, Harley S L and Taylor R (2018) Neoproterozoic evolution and Cambrian reworking of ultrahigh temperature granulites in the Eastern Ghats Province, India J Metamorph Geol doi: 10.1111/jmg. 12451

Morrissey L J, Hand M and Kelsey D E (2015) Multi-stage metamorphism in the Rayner-Eastern Ghats Terrane: P-T-t constraints from the northern Prince Charles Mountains, east Antarctic Precamb Res 267 137-163

Morrissey L J, Hand M, Kelsey D E and Wade B P (2016) Cambrian high-temperature reworking of the RaynerEastern Ghats terrane: constraints from the northern Prince Charles Mountains region, East Antarctica J Petrol 57 5392

Nanda J, Gupta S and Hacker B (2018) U-Pb zircon and titanite ages from granulites of the Koraput area-evidence for Columbia, Rodinia and Gondwana from the Eastern Ghats Province, India Precamb Res 314 394-413

Nasipuri P, Corfu F and Bhattacharya A (2018) Eastern Ghats Province (India)-Rayner Complex (Antarctica) accretion: timing the event Lithosphere 10 523-529

Ramakrishnan M, Nanda J K and Augustin P (1998) Geological evolution of the Proterozoic Eastern Ghats mobile belt. In: Geological evolution of Proterozoic Eastern Ghats Mobile Belt (Eds. Ramakrishnan M, Paul D K and Mishra R N) pp 1-21Geol Surv Ind Spec Pub 44

Ranjan S, Upadhyay D, Abhinay K, Pruseth K L and Nanda J K (2018) Zircon geochronology of deformed alkaline rocks along the Eastern Ghats Belt margin: India-Antarctica connection and the Enderbia continent Precamb Res 310 407-424

Ravikant V (2019) Cambrian garnet Sm-Nd isotopic ages from 
the polydeformed Bolangir Anorthosite Complex, Eastern Ghats Belt, India: implications for intraplate orogeny coeval with Kuunga Orogeny during Gondwana assembly $J$ Geol 127 437-456

Rickers K, Mezger K and Raith M M (2001) Evolution of the continental crust in the Proterozoic Eastern Ghats Belt, and new constraints for Rodinia reconstruction: implications from $\mathrm{Sm}-\mathrm{Nd}, \mathrm{Rb}-\mathrm{Sr}$ and $\mathrm{Pb}-\mathrm{Pb}$ isotopes Precamb Res 112 183-212

Saha D, Mazumder R and Kar R (2017) Shallow marine to pelagic sediments from a dismembered ophiolite, Kandra, southern India - glimpses of ancient subduction zone related sedimentation Gond Res 49 21-41

Saikia D, Nasipuri P and Bhattacharya A (2018) In situ U-Th$\mathrm{Pb}$ total dating of polychronous monazite in the Koraput anorthosite pluton, Eastern Ghats Granulite Belt (India), and implications Geol Mag 155 209-228

Sain A and Saha D (2018) Structure and tectonics of a Mesoproterozoic ophiolite - insight from Kanigiri Ophiolite with a mélange zone, southern India Tectonophysics $\mathbf{7 4 4}$ 177-204

Sain A, Saha D, Joy S, Jelsma H and Armstrong R (2017) New SHRIMP age and microstructures from a deformed Atype granite, Kanigiri, southern India: constraining the hiatus between orogenic closure and post-orogenic rifting $J$ Geol 125 241-259

Sarkar T and Schenk V (2016) Early Mesoproterozoic (1.6-1.5 $\mathrm{Ga}$ granulite facies events in the Ongole domain: geodynamic significance and global correlation $J$ Metamorph Geol 34 765-784

Sawant A D, Gupta S, Clark C and Misra S (2017) The RauerRengali connection in the Indo- Antarctica amalgam: evidence from structure, metamorphism and geochronology. In: Crustal evolution of India and Antarctica: the supercontinent connection (Eds. Pant N C and Dasgupta S) pp 171-196 Geol Soc Lond Spec Pub 457

Shaw R K, Arima M, Kagami H, Fanning C A M, Shiraishi K and Motoyoshi Y (1997) Proterozoic events in the Eastern Ghats granulite belt, India: evidence from $\mathrm{Rb}-\mathrm{Sr}, \mathrm{Sm}-\mathrm{Nd}$ systematics, and SHRIMP dating J Geol 105 645-656
Singh A and Singh C (2019) Seismic imaging of the deep crustal structure beneath Eastern Ghats Mobile Belt (India): Crustal growth in the context of assembly of Rodinia and Gondwana supercontinents Precamb Res doi: 10.1016/ j.precamres.2019.105343

Subramanyam K S V, Santosh M, Yang Q-Y. Zhang Z, Balaram V and Reddy U V B (2016) Mesoproterozoic island arc magmatism along the south-eastern margin of the Indian Plate: Evidence from geochemistry and zircon $\mathrm{U}-\mathrm{Pb}$ ages of mafic plutonic complexes J Asian Earth Sci 130 116138

Tong L, Jahn B, Liu X, Liang X, Xu Y and Ionov D (2017) Ultramafic to mafic granulites from the Larsemann Hills, East Antarctica: geochemistry and tectonic implications $J$ Asian Earth Sci 145 679-690

Upadhyay D (2008) Alkaline magmatism along the southeastern margin of the Indian shield: implications for regional geodynamics and constraints on craton-Eastern Ghats Belt suturing Precamb Res 162 59-69

Upadhyay D, Gerdes A and Raith M M (2009) Unraveling sedimentary provenance and tectonothermal history of high to ultra-high temperature metapelites using zircon and monazite chemistry: a case study from the Eastern Ghats Belt, India $J$ Geol 117 665-683

Van Leeuwen A T D V, Morrissey L J, Kelsey D E and Raimondo $\mathrm{T}$ (2019) Recognition of Pan- African-aged metamorphism in the Fisher Terrane, central Prince Charles Mountains, East Antarctica J Geol Soc Lond doi: 10.1144/jgs2018146

Vijaya Kumar K, Leelanandam C and Ernst W G (2011) Formation and fragmentation of the Palaeoproterozoic supercontinent Columbia: evidence from the Eastern Ghats Granulite Belt, southeast India Int Geol Rev 53 1297-1311

Vijaya Kumar K, Ernst W G, Leelanandam C and Wooden J L (2019) SHRIMP U-Pb ages of zircons from mafic granulites of the Eastern Ghats Belt, SE India: implications for the evolution of the Palaeoproterozoic arc crust $J$ Asian Earth Sci 177 198-219. 